\title{
Enzyme-inorganic nanoflowers/alginate microbeads: An enzyme immobilization system and its potential application
}

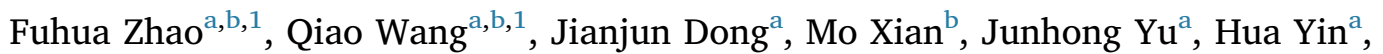 \\ Zongming Chang ${ }^{\mathrm{a}}$, Xindong $\mathrm{Mu}^{\mathrm{b}}$, Tonggang $\mathrm{Hou}^{\mathrm{b}, *}$, Jianxun Wang ${ }^{\mathrm{b}, *}$ \\ a State Key Laboratory of Biological Fermentation Engineering of Beer, Tsingtao Brewery Co. Ltd, Qingdao 266100, China \\ ${ }^{\mathrm{b}}$ Key Laboratory of Bio-based Materials, Qingdao Institute of Bioenergy and Bioprocess Technology, China Academy of Sciences, Qingdao, Shandong Province, 266101, \\ PR China
}

\section{A R T I C L E I N F O}

\section{Keywords:}

Enzyme-inorganic nanoflowers

Microbeads

Alginate

Enzyme immobilization

Diacetyl

\begin{abstract}
A B S T R A C T
In this work, novel nanoflower/alginate microbeads were synthesized to immobilize $\alpha$-acetolactate decarboxylase (ALDC) with a facile approach. Typically, ALDC was first coprecipitated with $\mathrm{Ca}_{3}\left(\mathrm{PO}_{4}\right)_{2}$ to form enzymeinorganic hybrid nanoflowers $\left(\mathrm{Ca}_{3}\left(\mathrm{PO}_{4}\right)_{2}\right.$ - $\left.\mathrm{ALDC}\right)$, and then the nanoflowers containing micrometre-sized particles and nanoscale flower-like petals were entrapped in alginate gel beads $\left(\mathrm{Ca}_{3}\left(\mathrm{PO}_{4}\right)_{2}\right.$-ALDC) @Alg). Compared with free ALDC and $\mathrm{Ca}_{3}\left(\mathrm{PO}_{4}\right)_{2}$-ALDC nanoflowers, the microbeads performed greatly improved recyclability and stability, meanwhile, retained $98 \%$ of activity compared with free ALDC. Moreover, the immobilized enzyme can be used in a $300 \mathrm{~L}$ beer fermentation tank to prevent the formation of diacetyl, solve the problem of beer off-flavor and short the beer maturation time, thus exhibiting a great potential application in beer brewing industry.
\end{abstract}

\section{Introduction}

In the main fermentation of beer, diacetyl is a by-product formed from $\alpha$-acetolactate, which could be further catalyzed to acetoin, but the residues of diacetyl in fermentation broth can lead to an unpleasant buttery taste in beer even with its concentration as low as $0.15 \mathrm{ppm}$ $[1,2]$. The rate-limiting step of fermentation is the conversion of $\alpha$ acetolactate into diacetyl, so the slow transformation lead to a long fermentation period of beer (2-12 weeks) [3,4]. $\alpha$-Acetolactate decarboxylase (ALDC (EC 4.1.1.5)) is an important enzyme during beer fermentation, which can prevent the formation of diacetyl by directly converting $\alpha$-acetolactate into flavorless acetoin (3-hydroxy-2-butanone) (Fig. 1), thus effectively solving the problem of beer off-flavor brought by diacetyl and shortening the beer maturation time as well. [4-6] Despite all the advantages, the industrial application of free ALDC is often hampered by the difficulties in recovery and recycling and a lack of long-term operational stability. Besides, the addition of exogenous enzymes may have a negative effect on beer flavour and peculiarity, and also improve the production cost. To overcome these drawbacks, immobilization of the enzyme on a suitable, food industryavailable supporting medium is an effective method. [7-11]

In recent years, nanobiocatalysis, in which enzymes are immobi- lized on/in nanostructured materials, has gathered growing attention due to its excellent performance in stabilizing/enhancing the enzymatic activity [12-19]. Hybrid protein-inorganic nanoflowers, first discovered by Zare's group, were synthesized through the co-precipitation of $\mathrm{Cu}_{3}\left(\mathrm{PO}_{4}\right)_{2}$ and proteins in an aqueous buffer solution, in which the activity of enzyme was remarkably enhanced [12]. Subsequently, protein-inorganic nanoflowers were prepared by other group through co-precipitation $\mathrm{Ca}^{2+}$ and enzyme[20,21]. Similarly, the enzymatic activity was also increased. However, the fatal disadvantage for nanobiocatalysis was low mechanical strength, which always lead to low stability for external environment [9]. Besides, the size of the nanobiocatalysis was often nano or micron scale, which made it difficult to separate nanomaterial from the substrate in producing operation [22]. As a nanobiocatalysis, nanoflower also has these drawbacks, which hinder their applications in industry.

Recently, hybrid materials, combining with the advantages of organic and inorganic components, have been widely applied for enzyme immobilization because of their unique properties [23-31]. Entrapment, one of the approaches employed in enzyme immobilization, can effectively protect the enzyme from external environment and offer commendable recyclability [32,33]. The supporting materials involving entrapment approach include pore glass beads [34], mem-

\footnotetext{
* Corresponding authors.

E-mail addresses: houtg@qibebt.ac.cn (T. Hou), wangjianxun@qibebt.ac.cn (J. Wang).

${ }^{1}$ Fuhua Zhao and Qiao Wang contributed equally.
} 


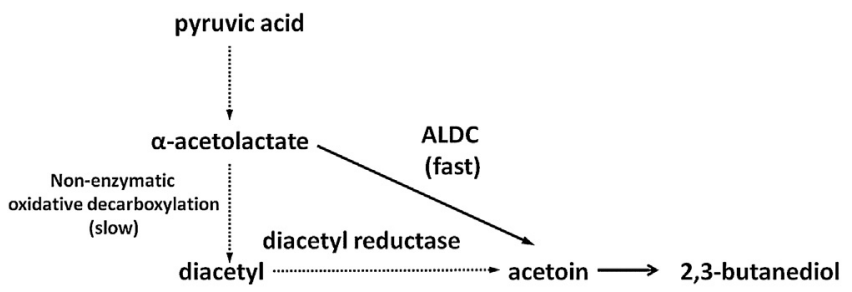

Fig. 1. The mechanism of ALDC enzymatic reaction.

branes [35], and polymer-/silica-based monolithic materials [7,36-38]. Among them, entrapment of enzymes in alginate polymer plays an important role in the field of enzyme immobilization due to the biocompatibility, thermo-stable properties and gel porosity of alginate [39-42]. Unfortunately, enzyme activity often lose seriously on the account of enzyme leakage and the diffusion limitation at the same time [43-46]. On the other hand, inorganic-enzyme hybrid nanoflowers often have enhanced activity but lower reusability. So, these two kinds of enzyme immobilization methods gave us a vital spark to assemble activity, stability and recyclability in one system. In this system, inorganic-enzyme nanoflowers were ingeniously entrapped in alginate and form a coalition where the two components conduct division of cooperation.

In this work, we reported a novel, versatile and cost effective method to construct enzymatic microbeads $\left(\mathrm{Ca}_{3}\left(\mathrm{PO}_{4}\right)_{2}\right.$-ALDC@Alg). ALDC was first coprecipitated with $\mathrm{Ca}_{3}\left(\mathrm{PO}_{4}\right)_{2}$ to form enzyme-inorganic hybrid nanoflowers $\left(\mathrm{Ca}_{3}\left(\mathrm{PO}_{4}\right)_{2}\right.$-ALDC) containing micrometresized particles and nanoscale flower-like petals, and then the nanoflowers were entrapped in alginate gel beads. During the preparation of the microbeads, no toxic substance was used, so it can be safely applied in food industry. The morphologies of $\mathrm{Ca}_{3}\left(\mathrm{PO}_{4}\right)_{2}$-ALDC nanoflowers and $\mathrm{Ca}_{3}\left(\mathrm{PO}_{4}\right)_{2}$-ALDC@Alg beads were observed through scanning electron microscopy (SEM). The enzyme immobilization yield, the properties of free and immobilized ALDC and the reusability of immobilized enzyme were investigated. Finally, the $\mathrm{Ca}_{3}\left(\mathrm{PO}_{4}\right)_{2}$ ALDC@Alg microbeads were used in a $300 \mathrm{~L}$ beer fermentation tank to investigate the ability of immobilized ALDC to prevent the formation of diacetyl.

\section{Experimental}

\subsection{Chemicals}

ALDC was provided by Tsingtao Brewery Co., Ltd. Ethyl-2-acetoxy2-methylacetoacetate was obtained from Sigma-Aldrich. Sodium alginate, calcium chloride $\left(\mathrm{CaCl}_{2}\right)$, 1-naphtol, and creatine were purchased from Sinopharm Chemical Reagent Co., Ltd. Other reagents were also provided by Sinopharm Chemical Reagent Co., Ltd. All the chemical reagents were of analytical grade and used as received without further purification. All aqueous solutions were prepared with deionized water.

\subsection{Preparation of $\mathrm{Ca}_{3}\left(\mathrm{PO}_{4}\right)_{2}-\mathrm{ALDC}$ nanoflowers}

The nanoflowers were synthesized by a co-precipitation method. In detail, firstly, a series of ALDC solution whose concentration ranged from 0 to $2 \mathrm{mg} \mathrm{mL}^{-1}$ were prepared in the phosphate buffer solution (4 mM, pH 7.4). Then, $90 \mu \mathrm{L}$ of $\mathrm{CaCl}_{2}$ solution $(200 \mathrm{mM}$ ) was added into $4.5 \mathrm{~mL}$ of the above-mentioned ALDC solution, followed by incubating the mixtures for $12 \mathrm{~h}$ at $25^{\circ} \mathrm{C}$. Finally, the solid products were collected by refrigerated centrifugation at $12000 \mathrm{rpm}$ for $10 \mathrm{~min}$ and washed with deionized water for three times to remove the nonspecifically adsorbed enzymes. The supernatant and washing liquid were collected together to determine the amount of enzyme immobilization.

\subsection{Preparation of $\mathrm{Ca}_{3}\left(\mathrm{PO}_{4}\right)_{2}$-ALDC@Alg and ALDC@Alg microbeads}

$26 \mathrm{mg}$ of $\mathrm{Ca}_{3}\left(\mathrm{PO}_{4}\right)_{2}$-ALDC nanoflowers, prepared with initial ALDC concentration of $1.2 \mathrm{mg} \mathrm{mL}^{-1}$, were dispersed in $10 \mathrm{~mL}$ of deionized water, and then added into $10 \mathrm{~mL}$ of sodium alginate colloidal solution ( $30 \mathrm{mg} \mathrm{mL}^{-1}$ ). The adequately blended mixture was dropwise pumped into an aqueous coagulation bath of $\mathrm{CaCl}_{2}(2.0 \mathrm{M}, 100 \mathrm{~mL})$ to form gel beads $\left(\mathrm{Ca}_{3}\left(\mathrm{PO}_{4}\right)_{2}\right.$-ALDC@Alg) by a syringe pump at a flow rate of $3 \mathrm{~mL} \mathrm{~min}^{-1}$ at room temperature. The beads were stirred and solidified in the $\mathrm{CaCl}_{2}$ bath for $15 \mathrm{~min}$ and then washed with deionized water for three times to remove the redundant $\mathrm{CaCl}_{2}$.

The ALDC@Alg microbeads were prepared with a similar method, except that $26 \mathrm{mg}$ of $\mathrm{Ca}_{3}\left(\mathrm{PO}_{4}\right)_{2}$-ALDC nanoflowers was replaced with $17 \mathrm{mg}$ ALDC.

\subsection{Evaluation of immobilization efficiency}

The centrifugal liquid collected in 2.2 part were pooled and the amount of un-immobilized enzyme in the liquid was determined by the Bradford method [47]. Briefly, $6 \mathrm{~mL}$ Bradford assay was added to $1 \mathrm{~mL}$ of a series of ALDC solution whose concentration was $0.125,0.25,0.5$, $1,2 \mathrm{mg} \mathrm{mL}^{-1}$, and the absorbance at $595 \mathrm{~nm}$ was detected using a UV/ vis spectrophotometer to formulate a standard curve. Then, $4 \mathrm{~mL}$ of Bradford assay was added to $1 \mathrm{~mL}$ of the supernatant and the absorbance at $595 \mathrm{~nm}$ was detected to calculate the concentration according to the standard curve. The amount of enzyme immobilized in the gel beads was calculated by subtracting the amount of unimmobilized enzyme from the total amount of the ALDC used for immobilization.

Immobilization efficiency $=\frac{\text { The amount of immobilized ALDC }}{\text { The total amount of the ALDC employed }}$

\subsection{Activity evaluation}

ALDC can directly transform $\alpha$-acetolactate into acetoin. The activities of free and immobilized ALDC were evaluated by calculating the rate of acetoin production under the standard conditions according to the method described elsewhere [2], with $\alpha$-acetolactate as substrate. $\alpha$-Acetolactate substrate was prepared by the following method: $5 \mu \mathrm{L}$ of ethyl-2-acetoxy-2-methylacetoacetate, $40 \mu \mathrm{L}$ of deionized water and $55 \mu \mathrm{L}$ of $\mathrm{NaOH}$ solution $\left(1 \mathrm{~mol} \mathrm{~L}^{-1}\right)$ was mixed and incubated at $0{ }^{\circ} \mathrm{C}$ for $15 \mathrm{~min}$, following that $0.9 \mathrm{~mL}$ MES (pH 6.0) was added.

$320 \mu \mathrm{L}$ of MES (pH 6.0) containing $1 \mathrm{mg}$ free ALDC and $80 \mu \mathrm{L}$ of $\alpha$ acetolactate substrate was mixed and incubated at $30^{\circ} \mathrm{C}$ for $20 \mathrm{~min}$. Then, $4.6 \mathrm{~mL}$ of chromogenic agent ( $1 \%$ of $\alpha$-naphthol and $0.1 \%$ of creatine in $1 \mathrm{~mol} \mathrm{~L}^{-1}$ of sodium hydroxide solution) was added to react with acetoin at $30{ }^{\circ} \mathrm{C}$ for $40 \mathrm{~min}$, resulting in the formation of a redcolored product. The absorbance of the red product was measured at $522 \mathrm{~nm}$ to confirm the concentration of acetoin generated from $\alpha$ acetolactate.

Activities of free and immobilized $\alpha$-ALDC were measured at the conditions of $30^{\circ} \mathrm{C}$ and $\mathrm{pH}$. The activity of free ALDC was set to $100 \%$, and the enzymatic activities of $\mathrm{Ca}_{3}(\mathrm{PO} 4)_{2}-\mathrm{ALDC}, \mathrm{Ca}_{3}\left(\mathrm{PO}_{4}\right)_{2^{-}}$ ALDC@Alg and ALDC@Alg were the activities relative to free ALDC.

The effects of $\mathrm{pH}$ and temperature on activities of free and immobilized ALDC were investigated with $\mathrm{pH}$ ranging from 3.5 to 8.0 and temperature ranging from 40 to $80{ }^{\circ} \mathrm{C}$. The highest activity was set as $100 \%$ in the two groups of experiments, respectively.

In the reusability examination, the first-run activity of each immobilized enzyme was taken as $100 \%$.

\subsection{Application of immobilized enzyme during beer fermentation}

ALDC was immobilized in $\mathrm{Ca}_{3}\left(\mathrm{PO}_{4}\right)_{2}$-ALDC@Alg gel beads, and all 
the beads were packaged into several strainers and sealed. Then, all the strainers were thrown into 300L of beer fermentation tank. The concentration of remaining diacetyl in fermentation broth were measured every day to assess the efficiency of immobilized $\alpha$-ALDC for preventing diacetyl production.

\subsection{Instrumentation}

Scanning electron microscopy (SEM) images were obtained with a Hitachi S-4800 equipment (Hitachi, Japan) operated at $5 \mathrm{kV}$. UV-vis absorption spectra were recorded on a Hitachi U-4100 Spectrometers (Hitachi, Japan) at room temperature. Energy-dispersive X-ray spectroscopy analysis was also recorded with a Hitachi S-4800 SEM. The concentration of diacetyl was inspected by using a waters 1525 highperformance liquid chromatograph (waters, America).

\section{Results and discussion}

\subsection{Preparation and characterization of $\mathrm{Ca}_{3}\left(\mathrm{PO}_{4}\right)_{2}$-ALDC nanoflowers}

The $\mathrm{Ca}_{3}\left(\mathrm{PO}_{4}\right)_{2}$-ALDC nanoflowers was synthesised in one pot by a modified method based on the work of Wang et al. [21] The synthesis mechanisms were illustrated in Fig. 2a. Briefly, $90 \mu \mathrm{L}$ of $200 \mathrm{mM} \mathrm{CaCl}_{2}$ solution was added into $4.5 \mathrm{~mL}$ of phosphate buffer solution $(4 \mathrm{mM}, \mathrm{pH}$ 7.4) containing ALDC at room temperature. The mixtures were incubated for $12 \mathrm{~h}$, obtaining a white precipitate with porous, flowerlike structures.

The effect of ALDC concentration on the formation of hybrid nanoflowers was investigated (Fig. 3). Fig. 3a showed that primary crystals of calcium phosphate could be formed when no enzyme added, which formed the scaffold of nanoflowers. When PSEP was added, protein molecules formed complexes with $\mathrm{Ca}^{2+}$, predominantly through the coordination facility of amide groups in the protein backbone. These complexes provided a location for nucleation of the primary crystals and then combined into large agglomerates to form the primary petals, followed by blossoming into nanoflowers [20]. The corresponding elemental mapping images in Fig. $3 \mathrm{j}$ confirmed the homogenous $\mathrm{Ca}$, $\mathrm{P}$ and $\mathrm{C}$ distribution in $\mathrm{Ca}_{3}\left(\mathrm{PO}_{4}\right)_{2}$ - $\mathrm{ALDC}$, which also verified the scaffold role of calcium phosphate and the successful compositing of calcium phosphate and enzyme in the hybrid nanoflowers. As can be seen from Fig. 3a, b, when the ALDC concentration was in the range of $0-0.1 \mathrm{mg} \mathrm{mL}^{-1}$, large crystals, but no nanoflowers were formed. When the concentration of ALDC increased to $0.2-1.2 \mathrm{mg} \mathrm{mL}^{-1}$, the multi-layered flower-like nanostructures were gradually formed, and the average diameters of these nanoflowers was about $4 \mu \mathrm{m}$ (Fig. 3c-g). When increasing the concentration of ALDC above $1.2 \mathrm{mg} \mathrm{mL}^{-1}$, the nanoflower structure was damaged and even aggregated into irregular clumps (Fig. 3h, i). With increasing the concentration of ALDC, the morphology of the nanoflowers changed significantly, which demonstrated that the concentration of enzyme had a fatal influence on the formation of enzyme-inorganic hybrid nanoflowers.

The amount of enzyme loading and enzyme immobilization efficiency in the $\mathrm{Ca}_{3}\left(\mathrm{PO}_{4}\right)_{2}$-ALDC nanoflowers was also investigated. As shown in Table 1, with the increase of ALDC initial concentration, the amount of enzyme loading increased from 0.92 to $23.84 \mathrm{mg} \mathrm{mg}^{-1}$, and the immobilization efficiency decrease gradually from $100 \%$ to $65 \%$. Remarkably, when the initial enzyme concentration was $1.2 \mathrm{mg} \mathrm{mL}^{-1}$, the amount of enzyme loading was $14.42 \mathrm{mg} / \mathrm{mg}$ and the immobilization efficiency was $70 \%$. It is a relative excellent data if the nanoflower prepared in this situation was used as immobilized enzyme.

\subsection{Preparation and characterization of $\mathrm{Ca}_{3}\left(\mathrm{PO}_{4}\right)_{2}-\mathrm{ALDC} @ A l g$ mircobeads}

The preparation of $\mathrm{Ca}_{3}\left(\mathrm{PO}_{4}\right)_{2}$-ALDC@Alg microbeads was based on our previous work [48], illustrated in Fig. 2b. In brief, $\mathrm{Ca}_{3}\left(\mathrm{PO}_{4}\right)_{2}$-ALDC nanoflowers were adequately dispersed in the sodium alginate solution to form a uniform solution. The mixture solution was then pumped into calcium chloride aqueous solution for ionically crosslinking to form $\mathrm{Ca}_{3}\left(\mathrm{PO}_{4}\right)_{2}$-ALDC @Alg beads. As a comparison, ALDC@Alg microbeads were prepared with the similar method that direct encapsulation of GOD within sodium alginate beads. As shown in Fig. 4a (inset), all the beads had a uniform and smooth spherical shape with an average diameter of around $2.7 \mathrm{~mm}$. Fig. 3k, 1 exhibited the surface and section SEM images of freeze drying $\mathrm{Ca}_{3}\left(\mathrm{PO}_{4}\right)_{2}$-ALDC@Alg microbeads, which clearly revealed the surface and internal structures of microbeads. The shrinkage and porous structure of the microbeads implied that there

(a)
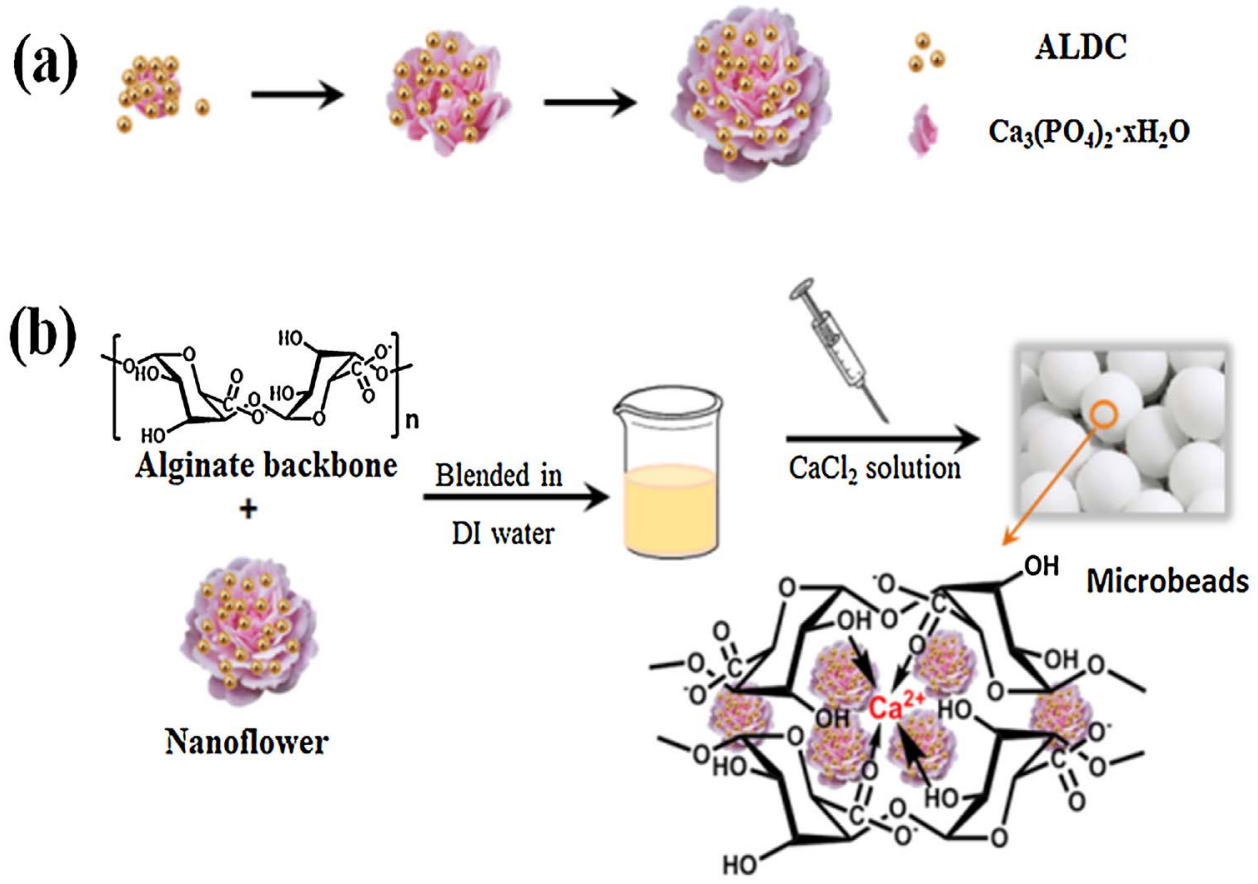

Fig. 2. Proposed growth mechanism of nanoflowers (a) and schematic representation of the synthesis of $\mathrm{Ca}_{3}\left(\mathrm{PO}_{4}\right)_{2}-\mathrm{ALDC}_{\mathrm{A}} \mathrm{Alg}$ microbeads (b). 

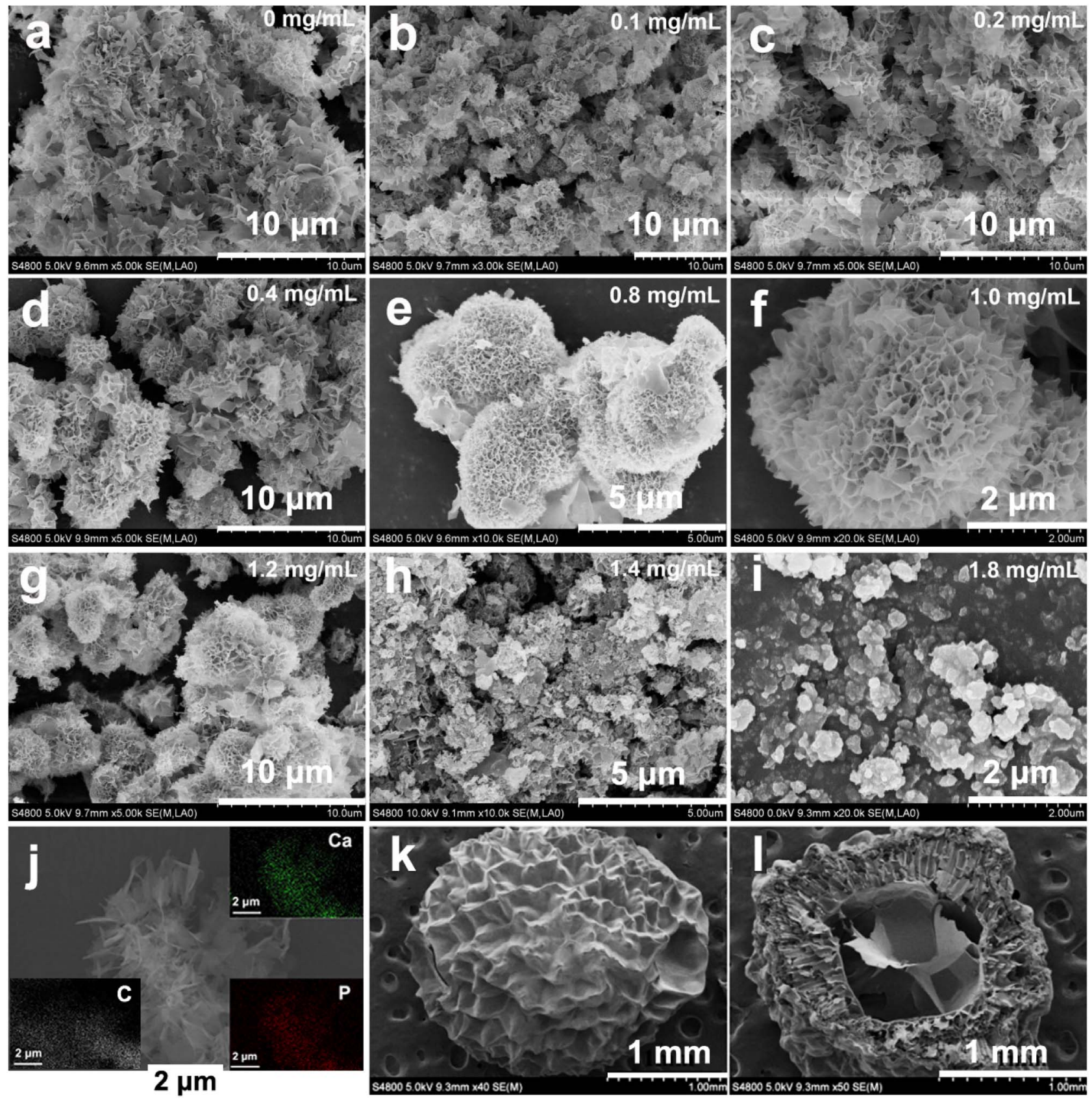

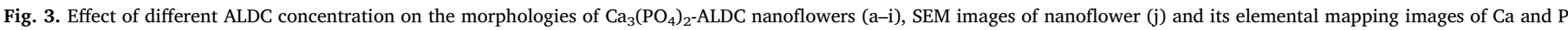

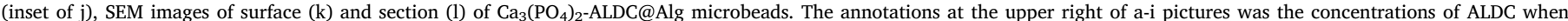
preparing the corresponding nanoflowers.

were a large number of internal spaces for substrate being catalyzed [49].

To confirm the successfully encapsulation of $\mathrm{Ca}_{3}\left(\mathrm{PO}_{4}\right)_{2}$-ALDC nanoflowers into alginate beads, the EDX analysis of $\mathrm{Ca}_{3}\left(\mathrm{PO}_{4}\right)_{2}$-ALDC@Alg microbeads was carried out. As shown in Fig. 4a, the microbeads contained $\mathrm{C}, \mathrm{N}, \mathrm{O}, \mathrm{P}, \mathrm{Cl}$ and $\mathrm{Ca}$ element. Among them, $\mathrm{N}$ element just came from enzyme and $\mathrm{P}$ element only came out of $\mathrm{Ca}_{3}\left(\mathrm{PO}_{4}\right)_{2}$, which demonstrated that the $\mathrm{Ca}_{3}\left(\mathrm{PO}_{4}\right)_{2}$-ALDC nanoflowers were entrapped in calcium alginate gel beads successfully.

\subsection{Activity assay}

The influence of ALDC initial concentration on the activities of nanoflowers was also observed. It was found in Fig. $4 \mathrm{~b}$ that the relative activities of nanoflowers increased from $28 \%$ to $120 \%$ with the concentrations of ALDC rising from 0 to $2 \mathrm{mg} \mathrm{mL}^{-1}$. Especially, when the concentration surpassed $1.2 \mathrm{mg} \mathrm{mL}^{-1}$, the activity of nanoflower exceeded $110 \%$. To take overall consideration of morphology, enzyme loading and enzyme immobilization efficiency, and the activities of nanoflowers, we selected $1.2 \mathrm{mg} \mathrm{mL}^{-1}$ as the initial ALDC concentration when preparing $\mathrm{Ca}_{3}\left(\mathrm{PO}_{4}\right)_{2}$-ALDC nanoflowers in the following experiment.

The activities of free ALDC, $\mathrm{Ca}_{3}\left(\mathrm{PO}_{4}\right)_{2}$-ALDC, ALDC@Alg and $\mathrm{Ca}_{3}\left(\mathrm{PO}_{4}\right)_{2}$-ALDC@Alg were assessed using $\alpha$-acetolactate as substrate based on the previous method [50]. All the activities mentioned in this paper were relative activities. Fig. $4 \mathrm{c}$ showed the relative specific activities of free ALDC, $\mathrm{Ca}_{3}\left(\mathrm{PO}_{4}\right)_{2}$-ALDC, ALDC@Alg and $\mathrm{Ca}_{3}\left(\mathrm{PO}_{4}\right)_{2}-$ ALDC@Alg. As is shown in Fig. 4c, the activity of $\mathrm{Ca}_{3}\left(\mathrm{PO}_{4}\right)_{2}$-ALDC nanoflowers increased by $10 \%$ compared with that of free ALDC, while the activity of ALDC@Alg decreased to about 70\%. The increased 
Table 1

The effect of initial ALDC concentration on the ability of ALDC loading in nanoflowers

\begin{tabular}{lllll}
\hline $\begin{array}{l}\text { Initial ALDC } \\
\text { concentration } \\
(\mathrm{mg} / \mathrm{ml})\end{array}$ & $\begin{array}{l}\text { Total } \\
\text { amount of } \\
\text { initial } \\
\text { ALDC }(\mathrm{mg})\end{array}$ & $\begin{array}{l}\text { Amount of } \\
\text { immobilized } \\
\text { ALDC }(\mathrm{mg})\end{array}$ & $\begin{array}{l}\text { Immobilization } \\
\text { efficiency } \\
(\%)\end{array}$ & $\begin{array}{l}\text { ALDC } \\
\text { loading } \\
\text { ALDC/ } \\
\mathrm{Ca}_{3}\left(\mathrm{PO}_{4}\right)_{2} \\
\left(\mathrm{mg} \mathrm{mg}^{-1}\right)\end{array}$ \\
\hline 0.05 & & & & 0.92 \\
0.1 & 2.25 & 2.25 & 100 & 1.71 \\
0.2 & 4.5 & 4.19 & 93 & 3.30 \\
0.6 & 9 & 8.09 & 90 & 9.37 \\
0.8 & 27 & 22.95 & 85 & 11.88 \\
1 & 36 & 29.11 & 81 & 13.37 \\
1.2 & 45 & 32.75 & 73 & 15.51 \\
1.4 & 54 & 38.01 & 70 & 17.09 \\
1.8 & 63 & 41.87 & 66 & 20.85 \\
2 & 81 & 51.03 & 63 & 23.84 \\
\hline
\end{tabular}

activity of nanoflowers can be explained by the action of allosteric effect and morphology. Firstly, it was confirmed that the $\mathrm{Ca}^{2+}$ could bind to specific functional sites of enzyme, which conversed inactive enzyme to active state. Secondly, nanoflowers enjoyed a higher surfaceto-volume ratio, which offered a large portion of immobilized ALDC. In consequence, ALDC in nanoflowers had increasing possibility to meet the substrate molecules [21]. The decreased activity of ALDC@Alg may be contributed to the diffusional limitation due to the porous in calcium alginate gel beads. When the micro and nano hierarchical structure of nanoflowers was involved in the gel beads, the merits of nanoflowers came into play, but the mass transfer still brought some adverse effect to the activity. So, the activity of $\mathrm{Ca}_{3}\left(\mathrm{PO}_{4}\right)_{2}$-ALDC@Alg gel beads was between $\mathrm{Ca}_{3}\left(\mathrm{PO}_{4}\right)_{2}$-ALDC nanoflowers and ALDC@Alg gel beads, around $98 \%$ activity of the free ALDC.

Generally speaking, immobilized enzyme, especially when entrapping enzymes in beads or capsules, often has the potential to change the microenvironment (such as temperature and $\mathrm{pH}$ ) surrounding enzyme molecules, thus improving the stability of the enzyme. In this work, the influences of $\mathrm{pH}$ and temperature on activity of free and immobilized ALDC were investigated (Fig. 5). Fig. 5a showed the effects of different $\mathrm{pH}$ values on the activities of free and immobilized ALDC. It showed that the optimized activities of free ALDC, $\mathrm{Ca}_{3}\left(\mathrm{PO}_{4}\right)_{2}$-ALDC, ALDC@Alg and $\mathrm{Ca}_{3}\left(\mathrm{PO}_{4}\right)_{2}$-ALDC@Alg were presented at pH 4.5, 4.5, 5.5 and 5.5, respectively. $\mathrm{Ca}_{3}\left(\mathrm{PO}_{4}\right)_{2}$-ALDC and $\mathrm{Ca}_{3}\left(\mathrm{PO}_{4}\right)_{2}$-ALDC@Alg were able to preserve more than $86 \%$ activities when the $\mathrm{pH}$ ranging from 3.5 to 7 . Obviously, $\mathrm{Ca}_{3}\left(\mathrm{PO}_{4}\right)_{2}$-ALDC and $\mathrm{Ca}_{3}\left(\mathrm{PO}_{4}\right)_{2}$-ALDC@Alg had a broader optimum $\mathrm{pH}$ extent than free ALDC (optimum $\mathrm{pH} 4.5-5$ ) and ALDC@Alg (optimum pH 5.5-7). Similar results were observed in the temperature effects on the activities of free and immobilized ALDC (Fig. 5b). It was noted that $\mathrm{Ca}_{3}\left(\mathrm{PO}_{4}\right)_{2}$-ALDC and $\mathrm{Ca}_{3}\left(\mathrm{PO}_{4}\right)_{2}$-ALDC@Alg performed a remarkable stability with relative activities exceeding $80 \%$ when the temperature ranged from 45 to $70{ }^{\circ} \mathrm{C}$. In comparison, the free ALDC and ALDC@Alg were only willing to show high activity at higher temperature $\left(65-70{ }^{\circ} \mathrm{C}\right.$ or $\left.55-70{ }^{\circ} \mathrm{C}\right)$. Considering the above data, $\mathrm{Ca}_{3}\left(\mathrm{PO}_{4}\right)_{2}$-ALDC and $\mathrm{Ca}_{3}\left(\mathrm{PO}_{4}\right)_{2}$-ALDC@Alg showed better stability towards $\mathrm{pH}$ and temperature because of the stabilizing influence of nanoflowers or gel beads to enzyme. However, comparing the two immobilized enzymes, $\mathrm{Ca}_{3}\left(\mathrm{PO}_{4}\right)_{2}$-ALDC@Alg microbeads was easier to recycle when the ALDC was used in the fermentation broth.

\subsection{Reusability}

A special property of immobilized enzyme is to recycle and reuse, so the reusability of immobilized enzyme is always taken into account for industrial application with the purpose of cost reduction. The reusability was evaluated by examining the remaining activity of immobilized ALDC after each cycle, and the specific activity in the first run was set to be $100 \%$. In this experiments, the microbeads of $\mathrm{Ca}_{3}\left(\mathrm{PO}_{4}\right)_{2}$ -
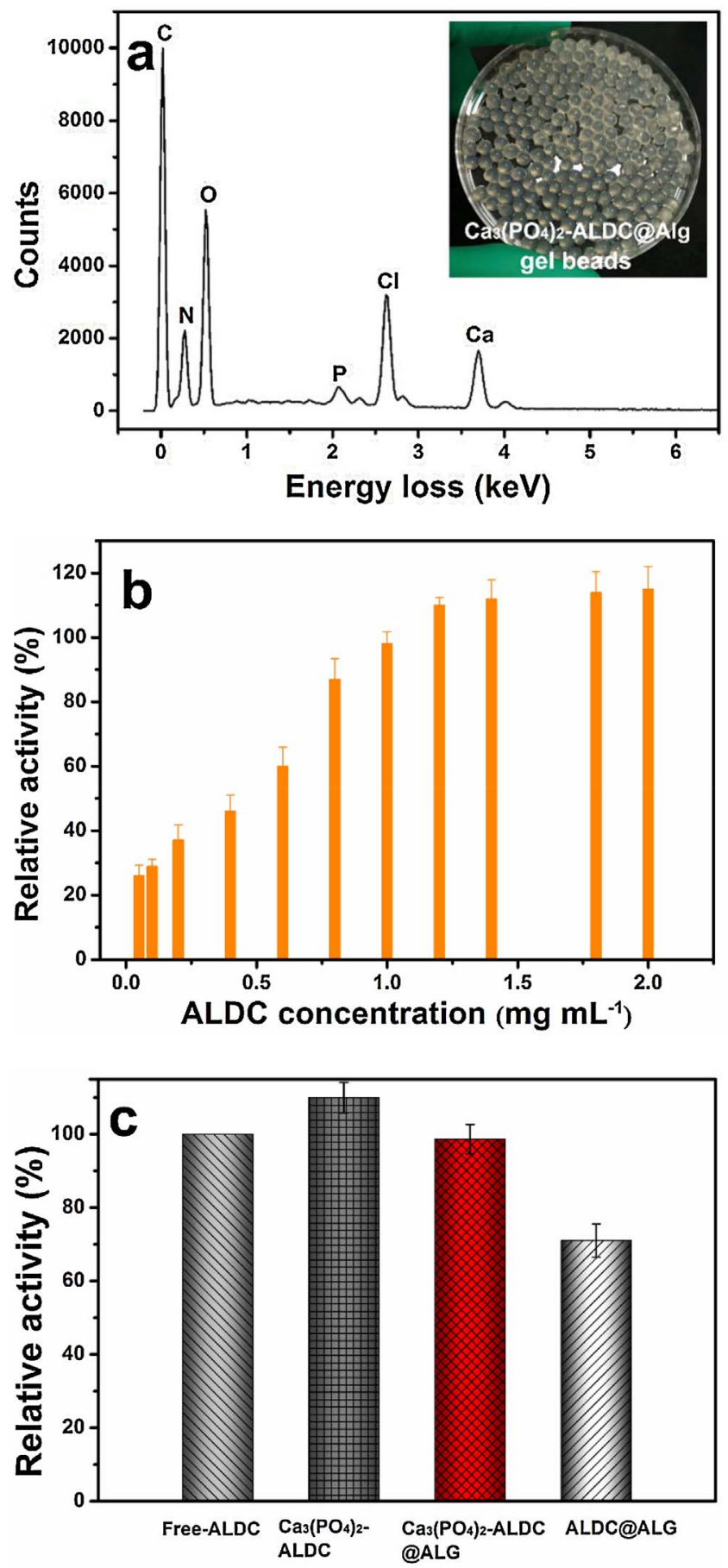

Fig. 4. EDX spectrum of the $\mathrm{Ca}_{3}\left(\mathrm{PO}_{4}\right)_{2}$-ALDC@Alg. Inset is the photo of $\mathrm{Ca}_{3}\left(\mathrm{PO}_{4}\right)_{2}$ ALDC@Alg gel beads (a). Effect of ALDC concentrations on relative activities of $\mathrm{Ca}_{3}\left(\mathrm{PO}_{4}\right)_{2}$-ALDC nanoflowers (b). Relative specific activities of free ALDC, $\mathrm{Ca}_{3}\left(\mathrm{PO}_{4}\right)_{2}$ ALDC, $\mathrm{Ca}_{3}\left(\mathrm{PO}_{4}\right)_{2}$-ALDC@Alg and ALDC@Alg. Activities of free and immobilized $\alpha$-ALDC were measured at the conditions of $30^{\circ} \mathrm{C}$ and $\mathrm{pH}$. The enzymatic activity of free ALDC was set to $100 \%$

ALDC@Alg and ALDC@Alg can be easily recycled by simple filtration even without using centrifugation or filtration under vacuum because of the larger size $\left(2.7 \mathrm{~mm}\right.$ in diameter), while the $\mathrm{Ca}_{3}\left(\mathrm{PO}_{4}\right)_{2}$-ALDC nanoflowers were separate from the reaction system by more complicated refrigerated centrifugation due to their tiny structure. Fig. 6a exhibited the recycling stability of the $\mathrm{Ca}_{3}\left(\mathrm{PO}_{4}\right)_{2}$-ALDC@Alg beads, with $\mathrm{Ca}_{3}\left(\mathrm{PO}_{4}\right)_{2}$-ALDC and ALDC@Alg as comparison. The results illustrated that the activity of ALDC@Alg decreased sharply even in the second round reaction and remained only about $22 \%$ of its initial 

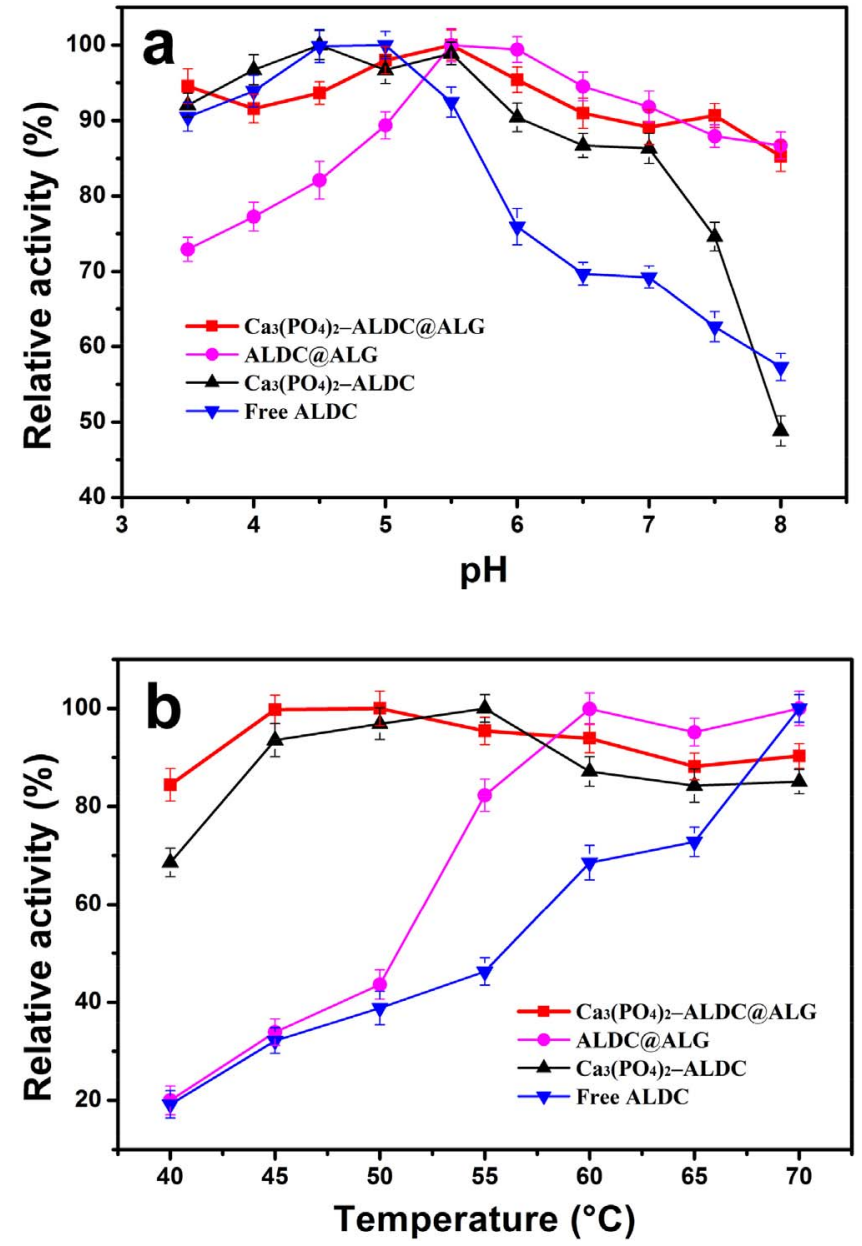

Fig. 5. Effect of pH (a) and temperature (b) on the activities of free ALDC, ALDC@Alg, $\mathrm{Ca}_{3}\left(\mathrm{PO}_{4}\right)_{2}$-ALDC and $\mathrm{Ca}_{3}\left(\mathrm{PO}_{4}\right)_{2}$-ALDC@Alg. The highest activity of each enzyme under its optimum temperature or $\mathrm{pH}$ was set to $100 \%$.

activity after six cycles, due to the serious leakage of enzyme from calcium alginate gel beads where physical entanglement played a major role between enzyme and carrier [51]. The reusability of $\mathrm{Ca}_{3}\left(\mathrm{PO}_{4}\right)_{2}$ ALDC was obviously enhanced compared with that of ALDC@Alg. However, the enzymatic activity decreased to $82 \%$ just at the second round, and only $55 \%$ of its initial activity was maintained after six cycles, which was probably because the nanoflowers were too small to be recycled totally. Interestingly, when embedding $\mathrm{Ca}_{3}\left(\mathrm{PO}_{4}\right)_{2}$-ALDC nanoflowers into calcium alginate gel beads, the reusability was further improved. For $\mathrm{Ca}_{3}\left(\mathrm{PO}_{4}\right)_{2}$-ALDC@Alg beads, above $80 \%$ of its original activity was retained even over six rounds reaction. The main driving force of the formation of $\mathrm{Ca}_{3}\left(\mathrm{PO}_{4}\right)_{2}$-ALDC nanoflowers was synergistic effect between $\mathrm{Ca}^{2+}$ and enzyme. When they were embedded into the calcium alginate gel beads, more complicated interaction occurred among enzyme, $\mathrm{Ca}_{3}\left(\mathrm{PO}_{4}\right)_{2}$ and calcium alginate network structure, which may be the reason that the reusability of the $\mathrm{Ca}_{3}\left(\mathrm{PO}_{4}\right)_{2}$ ALDC@Alg microbeads was improved compared with the other two immobilized enzymes. The convenient recovery and preferable reusability endow the $\mathrm{Ca}_{3}\left(\mathrm{PO}_{4}\right)_{2}$-ALDC@Alg beads potential application in beer brewing industry.

\subsection{Potential application in beer brewing industry}

This work attempted to carry out a preliminary discussion of the potential application of immobilized ALDC in beer brewing industry. Diacetyl reduction in beer was conducted using $\mathrm{Ca}_{3}\left(\mathrm{PO}_{4}\right)_{2}$-ALDC@Alg microbeads, and its effects were compared with conventionally aged
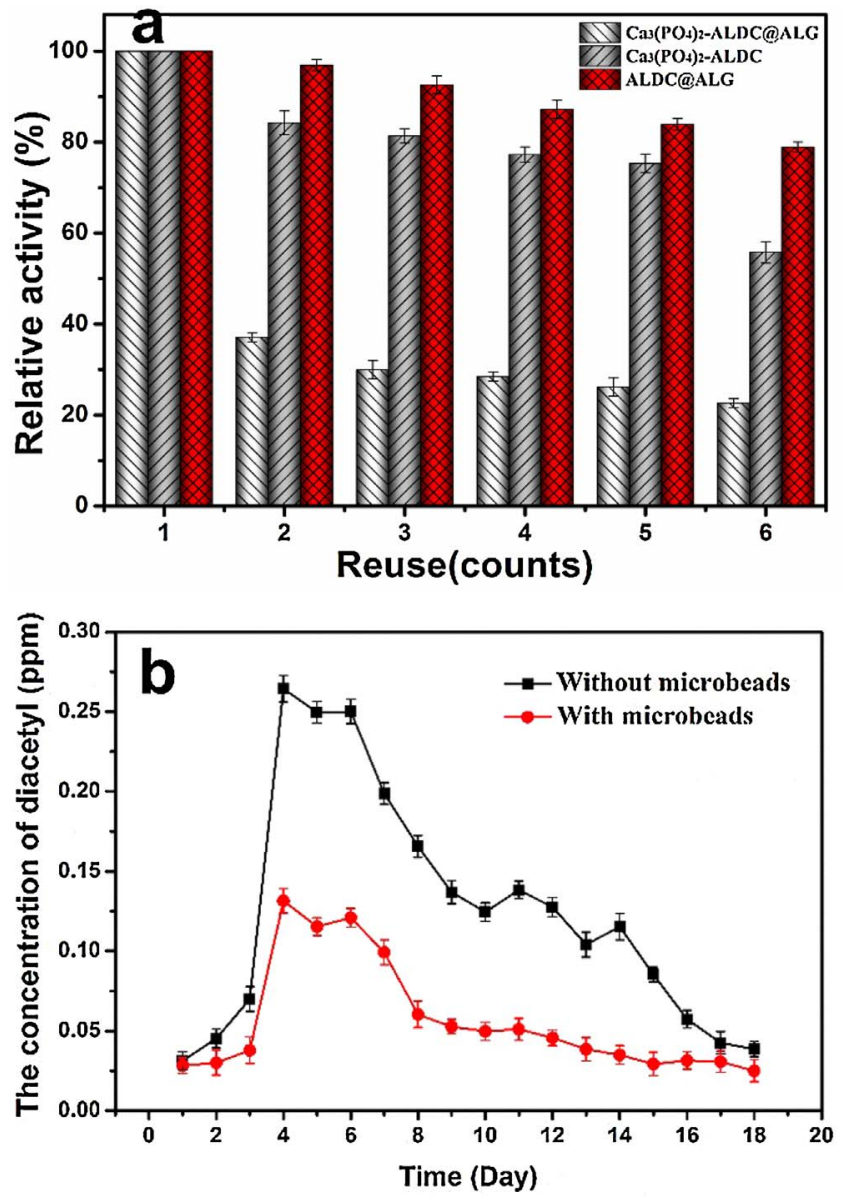

Fig. 6. Reusabilities of $\mathrm{Ca}_{3}\left(\mathrm{PO}_{4}\right)_{2}$-ALDC@Alg, ALDC@Alg and $\mathrm{Ca}_{3}\left(\mathrm{PO}_{4}\right)_{2}$-ALDC nanoflowers in catalyzing $\alpha$-acetolactate to acetion (a) and the concentration change of diacetyl in beer fermentation over time. The enzymatic activity of the first round was set to $100 \%$.

beer without ALDC. As shown in Fig. 7a, the $\mathrm{Ca}_{3}\left(\mathrm{PO}_{4}\right)_{2}$-ALDC@Alg microbeads was filled into several porous strainers, and then put them into a $300 \mathrm{~L}$ of beer fermentation tank. Another fermentation tank without microbeads acted as a control. The concentration of diacetyl in the two fermentation tanks was inspected every day, respectively. Fig. $6 \mathrm{~b}$ shows the concentration change of diacetyl in beer fermentation over time. As can be seen in Fig. 6b, when no microbeads existed in the tank, the diacetyl concentration reached a peak of $0.27 \mathrm{ppm}$ on the fourth day and maintained a high value $(0.27-0.25 \mathrm{ppm})$ for 3 days. The diacetyl levels in the beer dropped to below the threshold $(0.15 \mathrm{ppm})$ after eight days, but reached a low value (below $0.1 \mathrm{ppm}$ ) 15 days later. In comparison, when immobilized ALDC was added to the beer fermentation, the diacetyl peak also appeared on the fourth day, but the value (about $0.13 \mathrm{ppm}$ ) was significantly lower compared with that of the beer fermentation without enzyme ( 0.27 ppm, Fig. $6 \mathrm{~b})$, and which was below the threshold. The concentration of diacetyl decreased to below $0.1 \mathrm{ppm}$ even only 7 days later. Taken together, it is very effective for $\mathrm{Ca}_{3}\left(\mathrm{PO}_{4}\right)_{2}$-ALDC@Alg microbeads to quickly reduce the content of off-flavor diacetyl and shortening beer maturation time, because $\alpha$-acetolactate can be directly converted into flavorless acetoin by ALDC, thus preventing the formation of diacetyl.

Fig. 7b exhibited the photos of the $\mathrm{Ca}_{3}\left(\mathrm{PO}_{4}\right)_{2}$-ALDC@Alg microbeads before and after use in the beer fermentation tank. It was found that the microbeads were almost no damaged except for some colour change after use, which indicated the reliable mechanical strength of the mirobeads for recycling and recovery. In conclusion, the $\mathrm{Ca}_{3}\left(\mathrm{PO}_{4}\right)_{2^{-}}$ ALDC@Alg microbeads may have a great potential application in beer brewing industry in the future. 


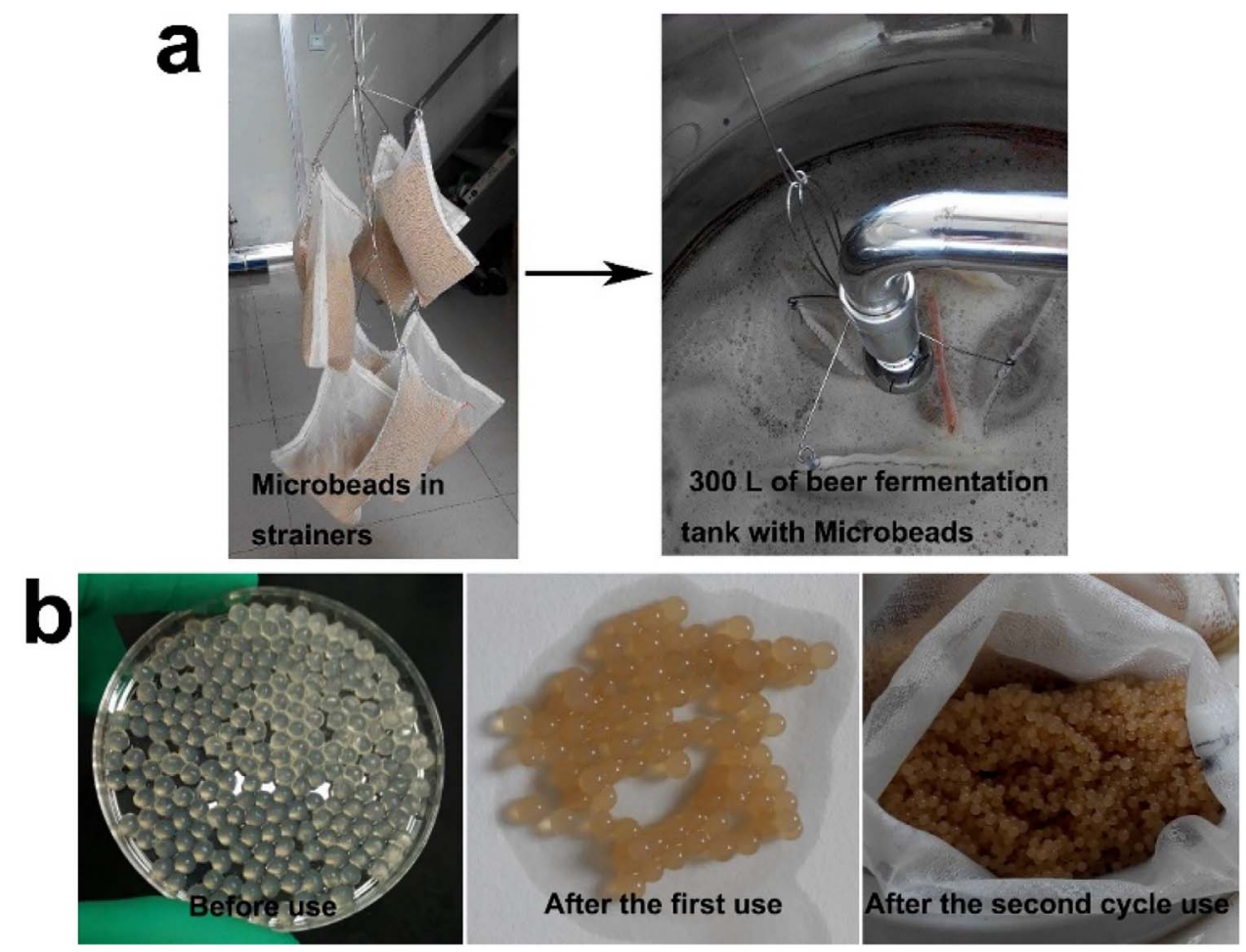

Fig. 7. The pictures of $\mathrm{Ca}_{3}\left(\mathrm{PO}_{4}\right)_{2}$-ALDC@Alg microbeads being used in beer fermentation tank (a) and the photos of $\mathrm{Ca}_{3}(\mathrm{PO})_{2}$ - $\mathrm{ALDC} @ \mathrm{Alg}$ microbeads before and after use.

\section{Conclusions}

In summary, we synthesized novel $\mathrm{Ca}_{3}\left(\mathrm{PO}_{4}\right)_{2}$-ALDC@Alg microbeads to immobilize ALDC with a facile approach. The microbeads could not only preserve commendable activity but perform excellent stability and environmental tolerance, showing optimum activity within a broad range ( $\mathrm{pH} 3.5-7$, temperature $\left.45-70{ }^{\circ} \mathrm{C}\right)$. The $\mathrm{Ca}_{3}\left(\mathrm{PO}_{4}\right)_{2}$-ALDC@Alg beads could be easily recycled by simple filtration and retained above $80 \%$ of its initial activity after six cycle use. Furthermore, the microbeads can be applied in beer fermentation tank to prevent the formation of diacetyl, solve the problem of beer off-flavor and short the beer maturation time, thus exhibiting a great potential application in beer brewing industry.

\section{Acknowledgments}

This work is supported by the National Natural Science Foundation of China (Grant No. 21433001; No. 21603251), and Applied Basic Research Foundation of Qingdao City (No. 14-2-4-21-jch).

\section{Appendix A. Supplementary data}

Supplementary data associated with this article can be found, in the online version, at http://dx.doi.org/10.1016/j.procbio.2017.03.026.

\section{References}

[1] C. Dulieu, M. Moll, J. Boudrant, D. Poncelet, Improved performances and control of beer fermentation using encapsulated alpha-acetolactate decarboxylase and modeling, Biotechnol. Prog. 16 (2000) 958-965.

[2] S. Qian, C. Wang, H. Wang, F. Yu, C. Zhang, H. Yu, Synthesis and characterization of surface-functionalized paramagnetic nanoparticles and their application to immobilization of alpha-acetolactate decarboxylase, Process Biochem. 50 (2015) 1388-1393.

[3] C.A. Masschelein, The biochemistry of maturation, J. Inst. Brew. 92 (1986) 213-219.

[4] E.J. Choi, H.W. Ahn, W.J. Kim, Effect of alpha-acetolactate decarboxylase on diacetyl content of beer, Food Sci. Biotechnol. 24 (2015) 1373-1380.

[5] S.E. Godtfredsen, M. Ottesen, Maturation of beer with alpha-acetolactate decarboxylase, Carlsberg Res. Commun. 47 (1982) 93-102.
[6] N. Akasaka, H. Sakoda, R. Hidese, Y. Ishii, S. Fujiwara, An efficient method using Gluconacetobacter europaeus to reduce an unfavorable flavor compound acetoin, in rice vinegar production, Appl. Environ. Microbiol. 79 (2013) 7334-7342.

[7] R.A. Sheldon, Enzyme immobilization: the quest for optimum performance, Adv. Synth. Catal. 349 (2007) 1289-1307.

[8] U. Hanefeld, L. Gardossi, E. Magner, Understanding enzyme immobilisation, Chem. Soc. Rev. 38 (2009) 453-468.

[9] R.A. Sheldon, S. van Pelt, Enzyme immobilisation in biocatalysis: why what and how, Chem. Soc. Rev. 42 (2013) 6223-6235.

[10] F.H. Zhao, H. Li, Y.J. Jiang, X.C. Wang, X.D. Mu, Co-immobilization of multienzyme on control-reduced graphene oxide by non-covalent bonds: an artificial biocatalytic system for the one-pot production of gluconic acid from starch, Green Chem. 16 (2014) 2558-2565.

[11] S. Zhang, Z. Jiang, J. Shi, X. Wang, P. Han, Qian W. An Efficient, Recyclable, and stable immobilized biocatalyst based on bioinspired microcapsules-in-hydrogel scaffolds, ACS Appl. Mater. Interfaces 8 (2016) 25152-25161.

[12] J. Ge, J. Lei, R.N. Zare, Protein-inorganic hybrid nanoflowers, Nat. Nanotechnol. 7 (2012) 428-432.

[13] L.-B. Wang, Y.-C. Wang, R. He, A. Zhuang, X. Wang, J. Zeng, J.G. Hou, A new nanobiocatalytic system based on allosteric effect with dramatically enhanced enzymatic performance, J. Am. Chem. Soc. 135 (2013) 1272-1275.

[14] Y. Yin, Y. Xiao, G. Lin, Q. Xiao, Z. Lin, Z. Cai, An enzyme-inorganic hybrid nanoflower based immobilized enzyme reactor with enhanced enzymatic activity, J. Mater. Chem. B 3 (2015) 2295-2300.

[15] Z. Lin, Y. Xiao, L. Wang, Y. Yin, J. Zheng, H. Yang, G. Chen, Facile synthesis of enzyme-inorganic hybrid nanoflowers and their application as an immobilized trypsin reactor for highly efficient protein digestion, RSC Adv. 4 (2014) 13888-13891.

[16] J.L. Zhang, F. Zhang, H.J. Yang, X.L. Huang, H. Liu, J.Y. Zhang, S.W. Guo, Graphene oxide as a matrix for enzyme immobilization, Langmuir 26 (2010) 6083-6085.

[17] C. Huang, H. Bai, C. Li, G. Shi, A graphene oxide/hemoglobin composite hydrogel for enzymatic catalysis in organic solvents, Chem. Commun. 47 (2011) 4962-4964.

[18] Y. Zhang, J.Y. Zhang, X.L. Huang, X.J. Zhou, H.X. Wu, S.W. Guo, Assembly of graphene oxide-enzyme conjugates through hydrophobic interaction, Small 8 (2012) 154-159.

[19] E. Zare-Eelanjegh, D.K. Bora, P. Rupper, K. Schrantz, L. Thöny-Meyer, K. ManiuraWeber, M. Richter, G. Faccio, Affinity-driven immobilization of proteins to hematite nanoparticles, ACS Appl. Mater. Interfaces 8 (2016) 20432-20439.

[20] J. Sun, J. Ge, W. Liu, M. Lan, H. Zhang, P. Wang, Y. Wang, Z. Niu, Multi-enzyme coembedded organic-inorganic hybrid nanoflowers: synthesis and application as a colorimetric sensor, Nanoscale 6 (2014) 255-262.

[21] L.-B. Wang, Y.-C. Wang, R. He, A. Zhuang, X. Wang, J. Zeng, J. Hou, A new nanobiocatalytic system based on allosteric effect with dramatically enhanced enzymatic performance, J. Am. Chem. Soc. 135 (2013) 1272-1275.

[22] K.M. Polizzi, A.S. Bommarius, J.M. Broering, J.F. Chaparro-Riggers, Stability of biocatalysts, Curr. Opin. Chem. Biol. 11 (2007) 220-225.

[23] S.A. Miller, E.D. Hong, D. Wright, Rapid and efficient enzyme encapsulation in a dendrimer silica nanocomposite, Macromol. Biosci. 6 (2006) 839-845. 
[24] R. Huang, M. Wu, M.J. Goldman, Z. Li, Encapsulation of enzyme via one-step template-free formation of stable organic inorganic capsules: a simple and efficient method for immobilizing enzyme with high activity and recyclability, Biotechnol. Bioeng. 112 (2015) 1092-1101.

[25] K. Ariga, Q.M. Ji, T. Mori, M. Naito, Y. Yamauchi, H. Abe, J.P. Hill, Enzyme nanoarchitectonics: organization and device application, Chem. Soc. Rev. 42 (2013) 6322-6345.

[26] F. Kurayama, S. Suzuki, N.M. Bahadur, T. Furusawa, H. Ota, M. Sato, N. Suzuki, Preparation of aminosilane-alginate hybrid microcapsules and their use for enzyme encapsulation, J. Mater. Chem. 22 (2012) 15405-15411.

[27] J. Kim, J.W. Grate, Single-enzyme nanoparticles armored by a nanometer-scale organic/inorganic network, Nano Lett. 3 (2003) 1219-1222.

[28] C. Hou, Y. Wang, H. Zhu, L. Zhou, Formulation of robust organic-inorganic hybrid magnetic microcapsules through hard-template mediated method for efficient enzyme immobilization, J. Mater. Chem. B 3 (2015) 2883-2891.

[29] L. Ma, W. Lu, J. Wen, Encapsulation of lactate dehydrogenase in carbon nanotube doped alginate-chitosan capsules, J. Mol. Catal. B-Enzym. 56 (2009) 102-107.

[30] D. Feng, T.-F. Liu, J. Su, M. Bosch, Z. Wei, W. Wan, D. Yuan, Y.-P. Chen, X. Wang, K. Wang, X. Lian, Z.-Y. Gu, J. Park, X. Zou, C. Zhou H-, Stable metal-organic frameworks containing single-molecule traps for enzyme encapsulation, Nat. Commun. 6 (2015).

[31] K.A. Mahmoud, K.B. Male, S. Hrapovic, J.H. Luong, Cellulose nanocrystal/gold nanoparticle composite as a matrix for enzyme immobilization, ACS Appl. Mater. Interfaces 1 (2009) 1383-1386.

[32] R. Sheldon, Cross-linked enzyme aggregates (CLEA ${ }^{\circ}$ s): stable and recyclable biocatalysts, Biochem. Syst. Ecol. 35 (2007) 1583-1587.

[33] W.-F. Lee, C.-T. Huang, Immobilization of trypsin by thermo-responsive hydrogel for the affinity separation of trypsin inhibitor, Desalination 234 (2008) 195-203.

[34] E. Yilmaz, K. Can, M. Sezgin, M. Yilmaz, Immobilization of Candida rugosa lipase on glass beads for enantioselective hydrolysis of racemic Naproxen methyl ester, Bioresour. Technol. 102 (2011) 499-506.

[35] P. Jochems, Y. Satyawali, L. Diels, W. Dejonghe, Enzyme immobilization on/in polymeric membranes: status: challenges and perspectives in biocatalytic membrane reactors (BMRs), Green Chem. 13 (2011) 1609-1623.

[36] J. Ma, C. Hou, Y. Liang, T. Wang, Z. Liang, L. Zhang, Y. Zhang, Efficient proteolysis using a regenerable metal-ion chelate immobilized enzyme reactor supported on organic?inorganic hybrid silica monolith, Proteomics 11 (2011) 991-995.

[37] Z. Zhou, M. Hartmann, Progress in enzyme immobilization in ordered mesoporous materials and related applications, Chem. Soc. Rev. 42 (2013) 3894-3912.
[38] A. Küchler, J. Adamcik, R. Mezzenga, A.D. Schlüter, P. Walde, Enzyme immobilization on silicate glass through simple adsorption of dendronized polymer-enzyme conjugates for localized enzymatic cascade reactions, RSC Adv. 5 (2015) 44530-44544.

[39] P. de Vos, M.M. Faas, B. Strand, R. Calafiore, Alginate-based microcapsules for immunoisolation of pancreatic islets, Biomaterials 27 (2006) 5603-5617.

[40] K.Y. Lee, D.J. Mooney, Alginate: properties and biomedical applications, Prog Polym. Sci. 37 (2012) 106-126.

[41] Z. Liu, H. Wang, B. Li, C. Liu, Y. Jiang, G. Yu, X. Mu, Biocompatible magnetic cellulose-chitosan hybrid gel microspheres reconstituted from ionic liquids for enzyme immobilization, J. Mater. Chem. 22 (2012) 15085-15091.

[42] A.R. Fajardo, M.B. Silva, L.C. Lopes, J.F. Piai, A.F. Rubira, E.C. Muniz, Hydrogel based on an alginate-Ca2 +/chondroitin sulfate matrix as a potential colon-specific drug delivery system, RSC Adv. 2 (2012) 11095.

[43] K. Won, S. Kim, K.-J. Kim, H.W. Park, S.-J. Moon, Optimization of lipase entrapment in Ca-alginate gel beads, Process Biochem. 40 (2005) 2149-2154.

[44] Z. Jiang, Y. Zhang, J. Li, W. Jiang, D. Yang, H. Wu, Encapsulation of $\beta$ glucuronidase in biomimetic alginate capsules for bioconversion of baicalin to baicalein, Ind. Eng. Chem. Res. 46 (2007) 1883-1890.

[45] I. Bhushan, R. Parshad, G.N. Qazi, V.K. Gupta, Immobilization of lipase by entrapment in Ca-alginate beads, J. Bioact. Compat. Polym. 23 (2008) 552-562.

[46] S. Gulay, G. Sanli-Mohamed, Immobilization of thermoalkalophilic recombinant esterase enzyme by entrapment in silicate coated Ca-alginate beads and its hydrolytic properties, Int. J. Biol. Macromol. 50 (2012) 545-551.

[47] B.M.M. Bradford, A rapid and sensitive method for the quantitation of microgram quantities of protein utilizing the principle of protein-dye binding, Anal. Biochem. 72 (2010).

[48] F. Zhao, H. Li, X. Wang, L. Wu, T. Hou, J. Guan, Y. Jiang, H. Xu, X. Mu, CRGO/ alginate microbeads: an enzyme immobilization system and its potential application for a continuous enzymatic reaction, J. Mater. Chem. B 3 (2015) 9315-9322.

[49] E.A. Manoel, M. Pinto, J.C.S. dos Santos, V.G. Tacias-Pascacio, D.M.G. Freire, J.C. Pinto, R. Fernandez-Lafuente, Design of a core-shell support to improve lipase features by immobilization, RSC Adv. 6 (2016) 62814-62824.

[50] A. Aitken, M.P. Learmonth, Protein determination by UV absorption, The Protein Protocols Handbook, (2002), pp. 3-6.

[51] H.G. Zhu, R. Srivastava, J.Q. Brown, M.J. McShane, Combined physical and chemical immobilization of glucose oxidase in alginate microspheres improves stability of encapsulation and activity, Bioconjugate Chem. 16 (2005) 1451-1458. 